\title{
T Lymphocyte Development and Activation in Humanized Mouse Model
}

\author{
Ji Yoon Lee, A-Reum Han, and 'Dong Ryul Lee \\ Dept. of Biomedical Science, CHA University, Seongnam 13488, Korea
}

\begin{abstract}
Humanized mice, containing engrafted human cells and tissues, are emerging as an important in vivo platform for studying human diseases. Since the development of Nod scid gamma (NSG) mice bearing mutations in the IL-2 receptor gamma chain, many investigators have used NSG mice engrafted with human hematopoietic stem cells (HSCs) to generate functional human immune systems in vivo, results in high efficacy of human cell engraftment. The development of NSG mice has allowed significant advances to be made in studies on several human diseases, including cancer and graft-versus-hostdisease (GVHD), and in regenerative medicine. Based on the human HSC transplantation, organ transplantation including thymus and liver in the renal capsule has been performed. Also, immune reconstruction of cells, of the lymphoid as well as myeloid lineages, has been partly accomplished. However, crosstalk between pluripotent stem cell derived therapeutic cells with human leukocyte antigen (HLA) mis/matched types and immune CD3 T cells have not been fully addressed. To overcome this hurdle, human major histocompatibility complex (MHC) molecules, not mouse MHC molecules, are required to generate functional $\mathrm{T}$ cells in a humanized mouse model. Here, we briefly summarize characteristics of the humanized mouse model, focusing on development of CD3 T cells with MHC molecules. We also highlight the necessity of the humanized mouse model for the treatment of various human diseases.
\end{abstract}

Key words : Humanized mouse model, T cell development, MHC mol-ecules, Stem cells

\section{INTRODUCTION}

Humanized mouse model is defined as immunodeficient mice engrafting functional human cells and tissues (Walsh et al., 2017). Generally, the humanized mouse model is reconstituted with human blood derived CD $34^{+}$stem cells from cord blood (CB), bone marrow (BM), and peripheral blood (PB) (Mosier et al., 1988; Lapidot et al., 1992; Shultz et al., 1995). Owing to continuous development of humanized mouse model, investigators have been able to study for immune response between human immune cells constructed from stem cells and therapeutic cell sources in vivo. Recipient mice are used as surrogates of human biol- ogy and diverse pathologic condition such as leukemia, breast cancer, autoimmune disease, and regenerative medicine (Lee et al., 2015). However, the mouse environment is incongruent with that seen in humans, for example, de novo drugs and human pathogens are species-specific and innate immune system (Walsh et al., 2017), thus, the humanized mouse model is considered as an important tool for biomedical research. In particular, it is an emerging as an in vivo platform to screen immune responses. Irradiated immunodeficient mice that receive human stem cells via intravenous injection and $\mathrm{CD} 4^{+}$stem cells migrated and engrafted into the BM, and subsequently circulated into PB after hematopoiesis. In order to model human immune

\footnotetext{
Manuscript received March 29, 2019, Received in revised form April 12, 2019, Accepted April 28, 2019

† Corresponding Author : Dong Ryul Lee, Department of Biomedical Science, CHA University, Seongnam 13488, Korea. Tel: +82-31-881-7136, E-mail: drleedr@cha.ac.kr
}

This is an Open Access article distributed under the terms of the Creative Commons Attribution Non-Commercial License (http:// creative-commons.org/licenses/by-nc/3.0) which permits unrestricted non-commercial use, distribution, and reproduction in any medium, provided the original work is properly cited. 
systems, investigators first have been studying immunodeficient mice using engrafted human cells from hematopoietic stem cells (HSCs) (McCune, 1988; Shultz et al., 2012). Additionally, humanized mice can facilitate studies on immune response caused by human leukocyte antigen (HLA) mismatching and on human diseases such as cancer (Henderson, 1994; Hu, 2016; Morton, 2016; Serr et al., 2016; Luce et al., 2018). A humanized model is required to study immune responses in vivo because results of in vitro culture conditions cannot properly represent immune crosstalk. Despite this requirement, humanized mouse models have limitations in terms of reconstruction of the hematolymphoid system due to insufficient availability of human epitopes. Although humanized mice maintain cross-reactivity by supporting the tolerance of the mouse cells towards transplanted human thymic tissues, regenerated $\mathrm{T}$ cells do not show adequate development for maturation with the HLA, which results in the failure of T cell activation (Obenaus, 2015; Kooreman et al., 2017). First, Ito M et al. and Shultz LD et al. developed advanced Nod scid gamma (NSG) (IL2rg ${ }^{\text {null }}$, NOD/ShiLtSz-scid/IL2Rg ${ }^{\text {null }}(\mathrm{NOD}$. $\mathrm{Cg}-$ Prkdc $c^{\mathrm{scid}} \mathrm{Il} 2 \mathrm{rg}^{\mathrm{tm} 1 \mathrm{Wjl} / \mathrm{SzJ})}$ mice, with a mutation in the IL-2Rr chain, which optimally support human $\mathrm{T}$ cell development (Ito et al., 2002; Shultz et al., 2005). Development of non-obese, diabetic mice with the Nod-scid gamma mutation was an advancement compared to the NSG mice developed previously. This proved to be a breakthrough in the development of humanized mouse models. This strain is more suitable for the generation of human $\mathrm{T}$ cells, as compared to the previous mouse strains such as C.Cg- $R$ ag2 $t$ mFwa I l2rg $t \mathrm{~m}$ Sug and C; 129S4- Rag2 $t$ mFlv I l2rgt m 1Flv/J. (Traggiai et al., 2004; Song et al., 2010). All strains showed enhanced engraftment of human HSCs, long life span, and production of functional immune responses, but, their efficacy was low. It was difficult to evaluate the crosstalk between lymphoid cells and pathogens. In this review, we summarize basic $\mathrm{T}$ cell development in the thymus of humanized mice, and suggest a so- lution to generate functional human $\mathrm{T}$ cells in a humanized mouse model. Also, we briefly review the achievements, recent trends, and the challenges in development of the humanized mouse model, which closely mimics human physiological environments in terms of hematology, immunology, and regenerative medicine.

\section{T CELL DEVELOPMENT IN HUMANIZED MICE}

Since Strowig T et al. showed that cytotoxic and cytokine releasing $\mathrm{T}$ cells can target latent Epstein-Barr virus (EBV) antigens using HLA-A2 transgenic mice (Strowig et al., 2009), Leonard D. Shultz et al. also reported the development of a homozygous major histocompatibility complex-I (MHC-I) expressing humanized mouse model, and demonstrated the functionality of cytotoxic human $\mathrm{T}$ cells (CTLs) in EBV infected humanized mice (Shultz et al., 2010). Many approaches using MHC mutations have allowed the establishment of HLA restricted humanized mouse models to study human immune systems (Watanabe et al., 2009; Jaiswal et al., 2012; Billerbeck et al., 2013; Thomas S, 2014). In the early stages of development of a humanized mouse model for $\mathrm{T}$ cell development, disease causing viruses, such as the EBV and the dengue virus that infect only humans, were mainly used to induce functional lymphocytes. Major or minor histocompatibility complexes including HLA-A2 and HLA-DR4 are common targets to induce genetic defects in a humanized mouse model. Danner R et al. reported the importance of HLA class II molecules in developing human lymphocytes, in a humanized mouse model (Danner, 2011). Several studies have consistently reported generation of HLA-DR restricted $\mathrm{T}$ cells with enhanced immunity in humanized mouse models (Suzuki, 2012; Billerbeck et al., 2013; Masse-Ranson et al., 2019). Although development of functional $\mathrm{T}$ cells in humanized mouse models has shown advancement in comparison to previous exper- 
iments, the production of $\mathrm{T}$ cells stimulated by human epitopes failed in xenograft models. To overcome this issue, amp-peptide with poly I:C, artificial mimetopes, and human viruses were directly injected into humanized mice (Serr et al., 2016; Coleman et al., 2018; Kruse, 2018). Also, the tumor associated antigen, Wilms tumor 1 (WT1), was recognized by human CD8 T cells in NSG mice (Najima et al., 2016). It was the first study to show that human mature $\mathrm{T}$ cells recognizing specific antigens can be generated in the humanized mouse model without genetic modification. These approaches have partly enabled us to reveal details of the dynamics of $\mathrm{T}$ cell reconstitution in humanized mice. To effectively investigate the crosstalk between immune cells and pluripotent stem cell derived cells in vivo, functional lymphocytes, which show HLA-restricted cytotoxicity, can be used. Although these trials have continuously enhanced cancer antigen specific $\mathrm{T}$ cells as well as HLA restricted $\mathrm{T}$ cells for regenerative medicine, the development of long-term hemato-lymphoid cells, including cytotoxic $\mathrm{T}$ lymphocytes (CTLs), in humanized mice is still in its infancy due to low alloreactivity (Andre, 2010; Kooreman et al., 2017). In vivo experiments for immune rejection by HLA types are considered crucial for the verification of stem cell derived therapeutic source safety in regenerative medicine. Because of obstacles related to in vitro studies in screening omnidirectional dynamics of immune responses, development of in vivo platforms such as humanized mouse models is essential. So far, there has been considerable advancement in the development of humanized mouse models and we propose the importance of HLA mis- and matched cells as a novel strategy to stimulate thymocyte development in advanced humanized mouse models, given the effective usage of HLA misand matched cells in stimulating the $\mathrm{CD} 4^{+} \mathrm{CD} 8^{+}$thymocytes (Fig. 1). We provide a simplified table with explanation for pros and cons of humanized mouse model by cell sources (Table 1).

\section{GENERAL DEVELOPMENT OF T LYMPHOCYTES AND INEFFICIENT ENVIRONMENT OF THYMUS IN HUMANIZED MICE}

In a humanized mouse model, blood cell reconstitution from adult HSCs was already confirmed in various conditions (Traggiai et al., 2004). HSCs are derived from human origins such as cord blood, bone marrow, and peripheral blood, but, thymic epithelial cells for human cell generation in a humanized mouse model are of mouse origin. Secondary lymphoid tissues (SLT) such as the thymus and lymph nodes are essential to completely mimic the human immune system in the mouse model (Takahama, 2006; Li et al., 2018). Amid these, human thymic epithelial cells, which express $\mathrm{MHC}$ molecules, have an affinity for $\mathrm{CD}^{+}$ and $\mathrm{CD} 8^{+} \mathrm{T}$ cells and play a role in the recognition, maturation, and development of lymphocytes (Li et al., 2005; Danner, 2011). Mouse has thymic epithelial cells with mouse MHC class molecules, such as $\mathrm{H}-2 \mathrm{~K}, \mathrm{H}-2 \mathrm{D}, \mathrm{H}-2 \mathrm{~L}$, $\mathrm{I}-\mathrm{A}$, and I-E, which affect the development of T cells. Because these molecules are not presented in a similar sequence as that of human MHC molecules, mouse thymic epithelial cells are fundamentally limited in mimicking human organs. However, mouse thymic epithelial cells are fundamentally limited in mimicking human organs, because mouse MHC molecules are not presented in a similar sequence as that of human HLA molecules. Lymphostromal interactions in the thymus play a pivotal role in $\mathrm{T}$ cell development and maturation based on the expression of $\mathrm{T}$ cell receptors (TCRs) during negative selection. The mouse thymic environment can partly provide specified cytokines required for the development of human $\mathrm{T}$ cells. However, the mouse MHC class is limited for the development of specific human HLA molecules, which ultimately results in failure of $\mathrm{T}$ cell development. These $\mathrm{T}$ cells are often biased and it failed to successfully present active human cell phenotypes, expressing CD45RO due to 

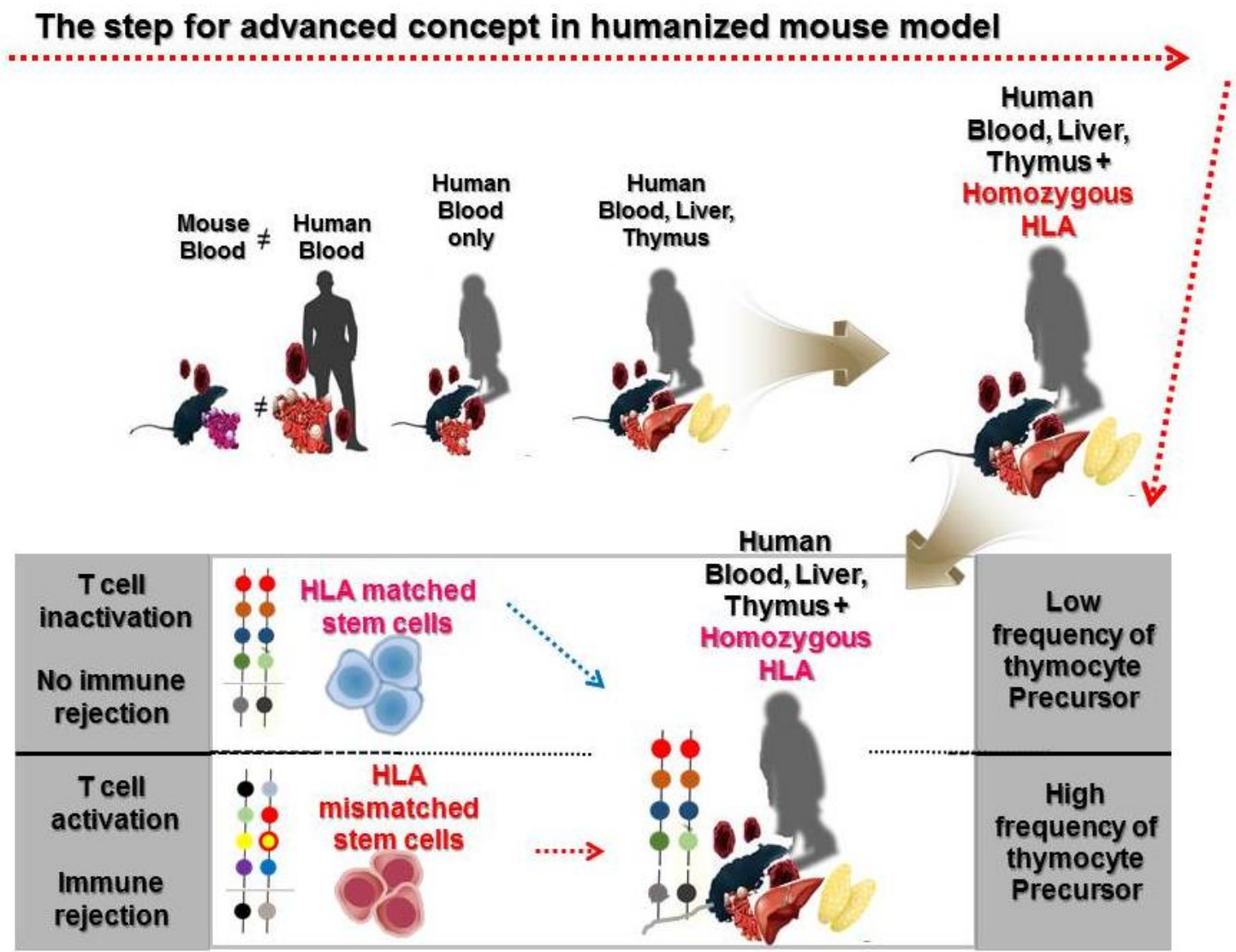

Fig. 1. The schematic diagram depicting the advancements in the concept of humanized mice model; xenografted mouse model has a limitation in providing information for crosstalk between human immune and stem cells. Next, BLT transplanted humanized mouse model allows mature thymic epithelial cells to effectively develop T cells, leading to SP cells. As future strategies, we also suggest that humanized mouse model using cord blood derived $\mathrm{CD}_{3} 4^{+}$cells with homozygous HLA will be used as a vivo platform to screen immune response by HLA (mis)matched types. BLT, bone marrow, liver, thymus; SP, single-positive; HLA, human leukocyte antigen.

insufficiency of human epitopes (Kooreman et al., 2017). T cells are derived from HSCs, which can differentiate into various lineages of blood cells. In the postnatal stage, HSCs are first generated in the bone marrow, and then migrate into the thymus via peripheral blood, and begin to develop into T cells (Lambolez, 2006; Takahama, 2006). The progenitors of $\mathrm{T}$ cells within the thymus are known as thymocytes, which undergo several steps of maturation. The degree of maturation of thymocytes can be identified in terms of expression of some cell surface markers. Early $\mathrm{T}$ lymphocyte progenitors in the cortex of the thymus are defined as double negative (DN) thymocytes, which do not express CD4 and CD8 co-receptors (Punt JA, 1996). These DN cells with the $\mathrm{CD} 44^{+} \mathrm{CD} 25^{+}$phenotype in the cortex can further differentiate into CD4 and CD8 double positive (DP) cells via TCR beta-selection (Prinz et al., 2006; Fayard et al., 2010). As selected cells have a stably rearranged TCR- $\beta$ chain locus, these cells successfully acquire CD3 molecules, and express the CD4 and CD8 coreceptors (Fehling, 1995; Bruno, 1996). In contrast, cells which cannot undergo beta-selection die via apoptosis. T cells that have survived beta-selection rearrange their TCR-alpha chain loci to produce an $\alpha \beta-T C R$ (Chan, 1993; Davis et al., 1993). Re-arrangement of TCR $\alpha$ locus has 
Table 1. The pros and cons of humanized mice by human stem cell and tissues transplantation

\begin{tabular}{|c|c|c|c|c|}
\hline & Cell sources & Pro & Con & Ref. \\
\hline \multirow{4}{*}{ PBL } & \multirow{4}{*}{$\begin{array}{l}\text { Human PB } \\
\text { lymphocyte }\end{array}$} & $\begin{array}{l}\text { 1. Easy to establish 2. GVHD } \\
\text { model }\end{array}$ & 1. Inability of human LT-HSC & $\begin{array}{c}\text { Mosier et al., 1988; } \\
\text { Tary-Lehmann et al., } 1995\end{array}$ \\
\hline & & $\begin{array}{l}\text { 2. Good model for } \\
\text { xenogeneic GVHD }\end{array}$ & $\begin{array}{l}\text { 2. Anergic naïve and memory } \\
\mathrm{T} \text { cells }\end{array}$ & $\begin{array}{c}\text { Gleichmann et al., 1984; } \\
\text { Garcia et al., 1997; } \\
\text { Tary-Lehmann and Saxon, } 1992\end{array}$ \\
\hline & & $\begin{array}{l}\text { 3. Initiation to generate } \\
\text { lymphoid cells }\end{array}$ & $\begin{array}{l}\text { 3. The lacks of functional hu- } \\
\text { man lymphoid cells }\end{array}$ & $\begin{array}{c}\text { Tsuchida et al., 1997; } \\
\text { Dessureault et al., 1997; } \\
\text { Tary-Lehmann and Saxon, } 1992\end{array}$ \\
\hline & & & $\begin{array}{l}\text { 4. Uncontrolled B cell activa- } \\
\text { tion }\end{array}$ & $\begin{array}{l}\text { Williams et al., 1992; } \\
\text { Abedi et al., 1992; } \\
\text { Gleichmann et al., } 1984\end{array}$ \\
\hline \multirow{3}{*}{ SRC } & \multirow{3}{*}{$\begin{array}{c}\text { Hemato- } \\
\text { poietic } \\
\text { stem cells } \\
\text { from a variety } \\
\text { of sources }\end{array}$} & 1. Establishment of LT-HSC & $\begin{array}{l}\text { 1. The lacks of educated hu- } \\
\text { man } T \text { cell }\end{array}$ & $\begin{array}{l}\text { Hiramatsu et al., 2003; } \\
\text { Ishikawa et al., 2005; } \\
\text { Melkus et al., } 2006\end{array}$ \\
\hline & & $\begin{array}{l}\text { 2. Generation of human } \\
\text { immune system }\end{array}$ & $\begin{array}{l}\text { 2. Restriction system for ge- } \\
\text { netic traits }\end{array}$ & $\begin{array}{l}\text { Cany et al., 2013; } \\
\text { McCune et al., 1988; } \\
\text { Smith et al., } 2016\end{array}$ \\
\hline & & $\begin{array}{l}\text { 3. High engraftment of NK } \\
\text { cells and CD3 lymphoid } \\
\text { cells }\end{array}$ & $\begin{array}{l}\text { 3. Uncontrolled or spontane- } \\
\text { ously generation of B cells } \\
\text { without maturation }\end{array}$ & $\begin{array}{c}\text { Manz, 2007; } \\
\text { Melkus et al., } 2006\end{array}$ \\
\hline \multirow{3}{*}{ BLT } & \multirow{3}{*}{$\begin{array}{l}\text { Human BM, } \\
\text { liver, thymus }\end{array}$} & $\begin{array}{l}\text { 1. Environmental mimicking } \\
\text { and complete human } \\
\text { immune system }\end{array}$ & $\begin{array}{l}\text { 1. Inadequate for all HLA } \\
\text { types }\end{array}$ & $\begin{array}{l}\text { McCune et al., 1988; } \\
\text { Wege et al., 2008; } \\
\text { Smith et al., 2016; } \\
\text { Melkus et al., 2006 }\end{array}$ \\
\hline & & $\begin{array}{l}\text { 2. Generation of HLA } \\
\text { restricted T cells }\end{array}$ & $\begin{array}{l}\text { 2. Requirement of human } \\
\text { epitopes for high diversity }\end{array}$ & $\begin{array}{l}\text { Shultz et al., 2010; } \\
\text { Takaki et al., 2006; } \\
\text { Niens et al., 2011; } \\
\text { Ishikawa et al., 2005 }\end{array}$ \\
\hline & & $\begin{array}{l}\text { 3. Human mucosal immune } \\
\text { system completion }\end{array}$ & $\begin{array}{l}\text { 3. The developmental } \\
\text { failure of GVHD }\end{array}$ & $\begin{array}{l}\text { McCune et al., 1988; } \\
\text { Lan et al., 2006; } \\
\text { Karpel et al., 2015; } \\
\text { Lavender et al., 2013 }\end{array}$ \\
\hline
\end{tabular}

PBL, peripheral blood lymphocyte; PB, peripheral blood; GVHD, graft-versus host disease; LT-HSC, long term hematopoietic stem cell; SRC, scid repopulating cells; NK, natural killer; BLT, bone marrow liver thymus; BM, bone marrow, HLA, human leukocyte antigen. 
been conducted; T cells expressing the full TCR as well as $\mathrm{CD} 4^{+} \mathrm{CD}^{+}$cells are termed "double-positive" (DP) cells. DP T cells are capable of interacting with MHC molecules. This involves the signal by double-positive precursors that express either MHC Class I or II restricted receptors. DP cells selected on MHC class I and II will become $\mathrm{CD} 8^{+}$ and $\mathrm{CD} 4^{+}$cells, respectively. The cells will become singlepositive, either $\mathrm{CD}^{+}$or $\mathrm{CD}^{+} \mathrm{T}$ cells ( $\mathrm{SP}$ cells), after downregulation of the non-selected co-receptors. SP cells then undergo negative selection, which is defined as tolerance of self by elimination of $\mathrm{T}$ cells binding with self MHC molecules in the medulla region. $\mathrm{T}$ lymphocytes become naïve CD4 or CD8 cells, which express CD45RA via negative selection step and then enter peripheral circulation (Fig. 2, left panel). Since T cells which have completely accomplished their development in thymus have functional acquirements in the peripheral circulation, negative selection in humanized mouse models must therefore be performed entirely by the human MHC molecules. To acquire the immune susceptibilities with high diversity for human cells, education of $\mathrm{T}$ cells by repetitively injecting mismatched human cells, as well as by transplantation of the human bone marrow, liver, thymus (BLT) transplantation. NSG mouse for humanized model partially supported the maturation of $\mathrm{T}$ and B cells (Peault et al., 1991; Ishikawa et al., 2005; Brainard et al., 2009); but thymus of NSG mice do not express HLA molecules (Thomas et al., 2014). Thus, NSG humanized mouse with T cell development lacks the capability to recognize human antigens in an HLA-restricted manner. To overcome the technical limitation, Shultz et al. developed the NSG-HLA-A2/HHD strain expressing HLA class I and showed the functional HLA-restricted cytotoxic $\mathrm{T}$ cells in the EBV infection, which is restricted HLA-A2 antigen. This indicates the recognition and education of human HLA in functional thymus of NSG (Shultz et al., 2010). Differentiation of T cells in NSG-HLA-A2/HHD mouse recapitulates the development of normal human $\mathrm{T}$ cells in vivo. The human $\mathrm{T}$ progenitors as well as humanized microenvironment are required to educate human $\mathrm{T}$ cells. From NSG-HLAA2/HHD mouse, advanced NSG mouse expressing the HLA class I molecules including HLA-A*0201 and A*2402 was established and developed by injection of human specific antigen WT1 peptides (Najima et al., 2016). This humanized mouse model led us to an advanced platform to study for immune stress response in terms of HLA mis/matched therapeutic stem cells and human viruses such as hepatotropic virus (Billerbeck et al., 2013). Although it is commonly believed that mouse thymus is not enough to entirely develop human $\mathrm{T}$ cells, the human mimicking signals, critical factor DLL4, and chemokines including Ccl25 and Cxcl12 may directly work to improve the thymic function and support diverse TCR repertoire (Zakrzewski et al., 2006; Halkias et al., 2013; Velardi et al., 2014). However, because mouse thymic environment for negative selection of human cells is insufficient, regulatory $\mathrm{T}$ cells (Treg cells) fail to functionally develop in NSG mice (Halkias et al., 2015); implying that $\mathrm{T}$ cell development still remains immature. To compensate thymic environment from humans, BLT seeding was applied in the humanized mouse model (Peault et al., 1991; Covassin et al., 2013; Brugman et al., 2015; Chung et al., 2015; Tuckett et al., 2017). Although BLT transplantation showed that donor specific HLA molecule is confirmatively augmented in medullary lymphocytes, lymphocytes are rapidly saturated in terms of transplanted cell numbers, suggesting the vitality of thymic epithelium rather than high HSCT cell numbers in T cell development. A brief schematic diagram for $\mathrm{T}$ cell development in the thymus is shown in Fig. 2 (right panel).

\section{STRATEGIES TO STIMULATE EFFEC- TOR/MEMORY T CELLS IN PERIPHERAL CIRCULATION}

$\mathrm{CD}^{+} \mathrm{T}$ cell responses are initiated in peripheral lym- 


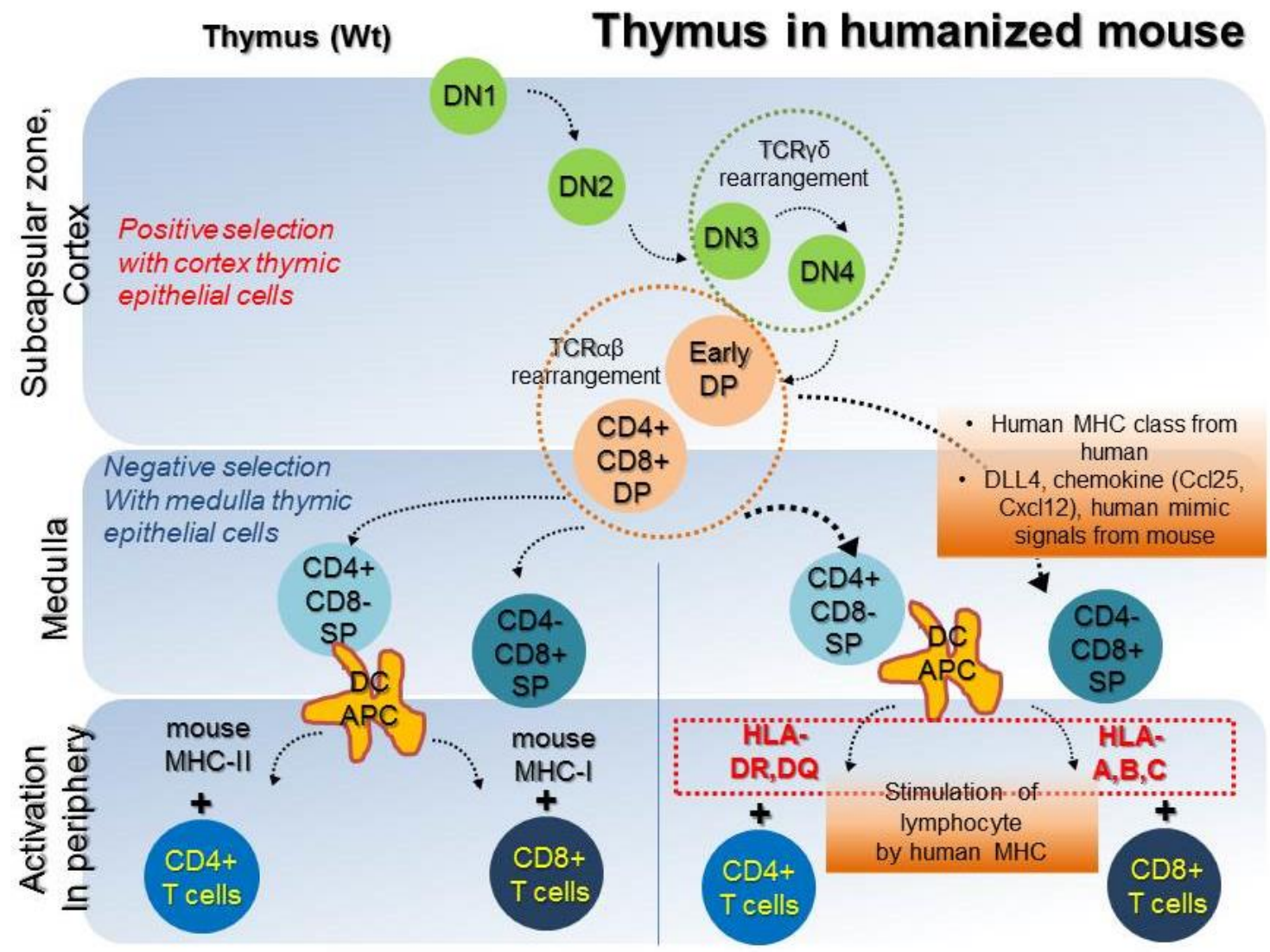

Fig. 2. The schematic diagram presents the development of $\mathbf{T}$ cells in thymus. Early $\mathrm{T}$ lymphocyte progenitors in cortex of the thymus are defined as double positive (DP) thymocytes. In the medulla region, DP precursors are acquired to facilitate maturation by MHC molecules. The negative selection procedure is completed by apoptotic cells which failed to eliminate the T cell receptor and to convert to single positive (SP) cells. Although thymus environment of mouse does not fully support HLA expression in T cells, human mimic factors including Notch signal factor DLL4 and chemokines such as Ccl25 and Cxcl12 can contribute expression of HLA molecules. MHC-I can bind with $\mathrm{CD}^{+} \mathrm{T}$ cells and MHC-II class has affinity towards $\mathrm{CD} 8^{+} \mathrm{T}$ cells. Matured $\mathrm{T}$ cells can provide information of immune response in terms of donor HLA molecules. MHC, major histocompatibility complex.

phoid organs by activated antigen presenting cells (APCs) such as dendritic cells and macrophages (Steinman, 1991; Ridge, 1998). Antigens need to migrate to lymphoid tissues via blood, lymph, and APCs. APCs ultimately provide antigen epitopes, also known as signal I, co-stimulatory cytokines such as CD28, CD80/CD86, CD40/CD40L, known as signal II, and cytokines including IFN-gamma, IL-12 and IL-4, known as signal III to naïve $\mathrm{T}$ cells (Fitzpatrick et al., 1996; Lenschow et al., 1996; Schoenberger, 1998; Murphy \& Reiner, 2002). Three factors are required to stimulate human $\mathrm{CD}^{+} \mathrm{T}$ cells. After binding of MHC molecules with antigens to TCRs on $\mathrm{T}$ cells, $\mathrm{T}$ cells get activated, differentiate, and expand into effector $\mathrm{T}$ cells. The roles of effector $\mathrm{T}$ cells in cell- and humoral-mediated immune responses have dynamic effects. Cytotoxicity against pathogens by $\mathrm{CD} 8^{+} \mathrm{T}$ cells, induction of antibody production in $\mathrm{B}$ cells by $\mathrm{CD} 4^{+}$helper $\mathrm{T}$ (Th1) cells, and suppression of regulatory $\mathrm{T}$ cells (Tregs) to enhance $\mathrm{T}$ cell function are mainly regulated by mature immune system. To investigate the immune stress response of $\mathrm{CD}^{+} \mathrm{T}$ cells in a humanized mouse model, development of immunity should be preceded by development of the thymus and 
lymphocyte development mediated by human MHC molecules. Melkus MW et al. first used superantigen toxic shock syndrome toxin 1 (TSST-1) recognizing dendritic cells in a humanized mouse model to reconstitute human $\mathrm{T}$ cells, suggesting that human antigens directly stimulate human T cells in humanized mice (Melkus et al., 2006). Based on this, Lan P et al. first reported successful establishment of a BLT humanized mouse model, wherein they transplanted human tissues including bone marrow derived blood cells, thymic epithelial cells and liver cells (McCune et al., 1991; Lan et al., 2006). An important achievement due to the BLT tissue transplant model as compared to stem $\mathrm{CD} 34^{+}$cells only transplant model, is the ability of engrafted mice to show high antiviral immune responses in vivo (Traggiai et al., 2004; Dudek et al., 2012; Klenerman \& Oxenius, 2016). However, this model does not allow long-term survival of humanized mice, and results in a failure of long-term immune response in vivo. Additionally, a long duration is required to achieve significant peripheral human effector T-cell repopulation in humanized mice. Most importantly, such mice show tolerance to human $\mathrm{T}$ cells along with lack of HLA restriction. However, the success of the model still remains undefined due to lack of fully stimulation by human HLA antigens. Recently, Kooreman NG et al. emphasized the necessity of allogenized mice, not that of humanized mice, to model the human immune system via allogeneic human embryonic stem cells (hESCs), implying that the humanized status without effector $\mathrm{T}$ cells is not completely adequate to achieve $\mathrm{T}$ lymphocyte activation to investigate immune rejection by HLA types (Kooreman et al., 2017). For an effective response, HLA molecules and anti-CD3/CD28 antibodies are required as specific ligands for activation of human $\mathrm{T}$ lymphocytes, which leads to an allogenized status. Alternatively, reconstruction of TAP-LAP was used to screen immunity by HLA alleles in humanized model. This transgenic mouse model enabled HLA-A molecules to be transported into endoplasmic reticulum, results in in- creased stability of humanized status in mouse (Huang et al., 2016). Tobias D et al also reported that generation of transgene expressing hypoimmunogenic cells, which modified with depletion of B2M, CIITA and overexpression of CD47, from induced pluripotent stem cells (iPSCs). They first carried out Elispot assay to address hypoimmunogenic properties of their modified iPSCs with splenocytes of humanized mouse model. This is the first evidence for HLA alleles of human cells in humanized mouse model (Deuse et al., 2019). A CD45RO-CD45RA ${ }^{+} \mathrm{CCR}^{+}$phenotype is a typical marker of naïve $\mathrm{T}$ cells. Expression of $\mathrm{CD}^{2} 5 \mathrm{RO}^{+} \mathrm{CD} 45 \mathrm{RA}^{-} \mathrm{CCR} 7^{+}$from human $\mathrm{CD} 8^{+}$cells (TCM), is widely considered to be a marker of central memory $\mathrm{T}$ cells. In contrast, the $\mathrm{CD}^{2} 5 \mathrm{RO}^{+} \mathrm{CD}^{2} 5 \mathrm{RA}^{-} \mathrm{CCR} 7^{-}$phenotype is regarded as a marker for $\mathrm{T}$ effector memory (TEM) cells, which function as cytotoxic $\mathrm{T}$ cells. In particular, CD27 and CD28 are not expressed in TEM cells (Lanzavecchia \& Sallusto, 2000; Romero et al., 2007). Thus, optimized lymphoid reconstruction should allow verification of expression of the mature effector $\mathrm{CD} 45 \mathrm{RO}^{+} \mathrm{CD}_{4} 5 \mathrm{RA}^{-}\left(\mathrm{CCR}^{+} /\right.$ $\mathrm{CCR}^{-}$) phenotype in $\mathrm{T}$ cells of the humanized mouse model for the alloimmune response of pluripotent stem cell derived cells.

\section{CONCLUSION}

Development of a humanized mouse model faces several barriers. Suppression of mouse immunity is required to effectively generate human lymphoid cells. Also, expression of HLA alleles is required for the development of human lymphoid immunity. Human specific factors and epitopes, which are not found in mice, must be used for functional lymphocyte development. In addition, reconstitution of a long-term lymphoid cell lineage is possible by the use of human cells. It will be important to investigate whether pluripotent derived stem cells can alter immune rejection responses, in terms of the HLA mis- or matched status, and if a humanized model presents an allogenized 
status to human HLA molecules. An advanced humanized mouse model will contribute to the analysis of the machinery underlying immunological interactions and recapitulating the humanized mouse model with effector $\mathrm{T}$ cells will provide insights for the development of therapeutic strategies.

\section{ACKNOWLEDGEMENTS}

This work was supported partly by the Bio \& Medical Technology Development Program (2017M3A9C6061284) and a Basic Science Research Program through the National Research Foundation of Korea (NRF) funded by the Ministry of Education (2017R1D1A1B03031406).

\section{REFERENCES}

Abedi MR, Christensson B, Islam KB, Hammarstorm L, Smith CL (1992) Immunoglobulin production in severe combined immunodeficient (SCID) mice reconstituted with human peripheral blood mononuclear cells. Eur J Immunol 22:823-828.

Andre MC, Erbacher A, Gille C, Schmauke V, Goecke B, Hohberger A, Mang P, Wilhelm A, Mueller I, Herr W, Lang P, Handgretinger R, Hartwig UF (2010) Longterm human $\mathrm{CD}^{+} 4^{+}$stem cell-engrafted nonobese diabetic/SCID/IL-2R gamma ${ }^{\text {null }}$ mice show impaired $\mathrm{CD}^{+} \mathrm{T}$ cell maintenance and a functional arrest of immature NK cells. J Immunol 185:2710-2720.

Billerbeck E, Horwitz JA, Labitt RN, Donovan BM, Vega K, Budell WC, Koo GC, Rice CM, Ploss A (2013) Characterization of human antiviral adaptive immune responses during hepatotropic virus infection in HLAtransgenic human immune system mice. J Immunol 191:1753-1764.

Brainard DM, Seung E, Frahm N, Cariappa A, Bailey CC, Hart WK, Shin HS, Brooks SF, Knight HL, Eichbaum Q, Yang YG, Sykes M, Walker BD, Freeman GJ, Pillai
S, Westmoreland SV, Brander C, Luster AD, Tager AM (2009) Induction of robust cellular and humoral virusspecific adaptive immune responses in human immunodeficiency virus-infected humanized BLT mice. J Virol 83:7305-7021.

Brugman $\mathrm{MH}$, Wiekmeijer AS, van Eggermond M, van Eggermond M, Wolvers-Tettero I, Langerak AW, de Hass EF, Bystrykh LV, van Rood JJ, de Haan G, Fibbe WE, Staal FJ (2015) Development of a diverse human $\mathrm{T}$-cell repertoire despite stringent restriction of hematopoietic clonality in the thymus. Proc Natl Acad Sci USA 112:E6020-6027.

Bruno L, Fehling HJ, von Boehmer H (1996) The alpha beta $\mathrm{T}$ cell receptor can replace the gamma delta receptor in the development of gamma delta lineage cells. Immunity 5:343-352.

Cany J, van der Waart AB, Tordoir M, Franssen GM, Hangalapura BN, de Vries J, Boerman O, Schaap N, van der Voort R, Spanholtz J, Dolstra H (2013) Natural killer cells generated from cord blood hematopoietic progenitor cells efficiently target bone marrow-residing human leukemia cells in NOD/SCID/IL2 $\mathrm{Rg}^{\text {null }}$ mice. PLOS ONE 8:e64384.

Chan SH, Cosgrove D, Waltzinger C, Benoist C, Mathis D (1993) Another view of the selective model of thymocyte selection. Cell 73:225-236.

Chung YS, Son JK, Choi B, Joo SY, Lee YS, Park JB, Moon H, Kim TJ, Kim SH, Hong S, Chang J, Kang MS, Kim SJ (2015) Co-transplantation of human fetal thymus, bone and $\mathrm{CD}_{34}\left(^{+}\right)$cells into young adult immunodeficient NOD/SCID IL2Rgamman ${ }^{\text {null }}$ mice optimizes humanized mice that mount adaptive antibody responses. Clin Immunol 157:156-165.

Coleman CB, Lang J, Sweet LA, Smith NA, Freed BM, Pan Z, Haverkos B, Pelanda R, Rochford R (2018) Epstein-barr virus type 2 infects $\mathrm{T}$ cells and induces $\mathrm{b}$ cell lymphomagenesis in humanized mice. J Virol 92:e00813-18. 
Covassin L, Jangalwe S, Jouvet N, Laning J, Burzenski L, Shultz LD, Brehm MA (2013) Human immune system development and survival of non-obese diabetic (NOD)scid IL2rgamma ${ }^{\text {null }}$ (NSG) mice engrafted with human thymus and autologous haematopoietic stem cells. Clin Exp Immunol 174:372-388.

Danner R, Chaudhari SN, Rosenberger J, Surls J, Richie TL, Brumeanu TD, Casarea S (2011) Expression of HLA class II molecules in humanized NOD.Rag1KO.IL $2 \mathrm{RgcKO}$ mice is critical for development and function of human T and B cells. PLOS ONE 6:e19826.

Davis CB, Killeen N, Crooks ME, Raulet D, Littman DR (1993) Evidence for a stochastic mechanism in the differentiation of mature subsets of $\mathrm{T}$ lymphocytes. Cell 73:237-247.

Dessureault S, Shpitz B, Alloo J, Rotstein O, Sandhu J, Hozumi N, Fernanders B, Gallinger S (1997) Physiologic human T-cell responses to OKT3 in the human peripheral blood lymphocyte-severe combined immunodeficiency mouse model. Transplantation 64:811-816.

Deuse T, Hu X, Gravina A, Wang D, Tediashivili G, De C, Thayer WO, Wahl A, Garcia JV, Reichenspurner H, Davis MM, Lanier LL, Schrepfer S (2019) Hypoimmunogenic derivatives of induced pluripotent stem cells evade immune rejection in fully immunocompetent allogeneic recipients. Nat Biotechnol 37:252258.

Dudek TE, No DC, Seung E, Vrbanac VD, Fadda L, Bhoumik P, Boutwell CL, Power KA, Gladden AD, Battis L, Mellors EF, Tivey TR, Gao X, Altferd M, Luster AD, Tager AM, Allen TM (2012) Rapid evolution of HIV-1 to functional $\mathrm{CD}^{+} \mathrm{T}$ cell responses in humanized BLT mice. Sci Transl Med 4:143ra98.

Fayard E, Moncayo G, Hemmings BA, Hollander GA (2010) Phosphatidylinositol 3-kinase signaling in thymocytes: The need for stringent control. Sci Signal 3:re5.

Fehling HJ, Krotkova A, Saint-Ruf C, von Boehmer H
(1995) Crucial role of the pre-T-cell receptor alpha gene in development of alpha beta but not gamma delta T cells. Nature 375:795-798.

Fitzpatrick L, Makrigiannis AP, Kaiser M, Hoskin DW (1996) Anti-CD3-activated killer T cells: Interferongamma and interleukin-10 cross-regulate granzyme B expression and the induction of major histocompati. bility complex-unrestricted cytotoxicity. J Interferon Cytokine Res 16:537-546.

Garcia S, Dadaglio G, Gougeon ML (1997) Limits of the human-PBL-SCID mice model: Severe restriction of the $\mathrm{V}$ beta $\mathrm{T}$-cell repertoire of engrafted human $\mathrm{T}$ cells. Blood 89:329-336.

Gleichmann E, Pals ST, Rolink AG, Radaszkiewicz T, Gleichmann H (1984) Graft-versus-host reactions: Clues to the etiopathology of a spectrum of immunological diseases. Immunol Today 5:324-332.

Halkias J, Melichar HJ, Taylor KT, Ross JO, Yen B, Cooper SB, Winoto A, Robey EA (2013) Opposing chemokine gradients control human thymocyte migration in situ. J Clin Invest 123:2131-2142.

Halkias J, Yen B, Taylor KT, Reinhartz O, Winoto A, Robey EA, Meichar HJ (2015) Conserved and divergent aspects of human T-cell development and migration in humanized mice. Immunol Cell Biol 93:716726.

Henderson DA (1994) Role of the United States in the global response to emerging infections. $\mathrm{J}$ Infect Dis 170:284-285.

Hiramatsu H, Nishikomori R, Heike T, Ito M, Kobayashi K, Katamura K, Nakahata T (2003) Complete reconstitution of human lymphocytes from cord blood CD34 $4^{+}$ cells using the NOD/SCID/gammac ${ }^{\text {null }}$ mice model. Blood 102:873-880.

Hu Z, Xia J, Fan W, Wargo J, Yang YG (2016) Human melanoma immunotherapy using tumor antigen-specific $\mathrm{T}$ cells generated in humanized mice. Oncotarget 7:6448-6459. 
Huang M, Zhang W, Guo J, Wei X, Phiwpan K, Zhang J, Zhou X (2016) Improved transgenic mouse model for studying HLA class I antigen presentation. Sci Rep $6: 33612$.

Ishikawa F, Yasukawa M, Lyons B, Yoshida S, Miyamoto T, Yoshimoto G, Watanabe T, Akashi K, Shultz LD, Harada M (2005) Development of functional human blood and immune systems in NOD/SCID/IL2 receptor y chain $^{\text {null }}$ mice. Blood 106:1565-1573.

Ito M, Hiramatsu H, Kobayashi K, Suzue K, Kawahata M, Hioki K, Ueyama Y, Koyanagi Y, Sugamura K, Tsuji K, Heike T, Nakahata T (2002) NOD/SCID/gamma(c) ${ }^{\text {null }}$ mouse: An excellent recipient mouse model for engraftment of human cells. Blood 100:3175-3182.

Jaiswal S, Pazoles P, Woda M, Shultz LD, Greiner DL, Brehm MA, Mathew A (2012) Enhanced humoral and HLA-A2-restricted dengue virus-specific T-cell responses in humanized BLT NSG mice. Immunology 136:334-343.

Karpel ME, Boutwell CL, Allen TM (2015) BLT humanized mice as a small animal model of HIV infection. Curr Opin Virol 13:75-80.

Klenerman P, Oxenius A (2016) T cell responses to cytomegalovirus. Nat Rev Immunol 16:367-377.

Kooreman NG, de Almeida PE, Stack JP, Nelakanti RV, Diecke S, Shao NY, Swijnenburg RJ, Sanchez-Freire V, Matsa E, Liu C, Connolly AJ, Hamming JF, Quax PHA, Brehm MA, Greiner DL, Shultz LD, Wu JC (2017) Alloimmune responses of humanized mice to human pluripotent stem cell therapeutics. Cell Rep 20:1978-1990.

Kruse S, Buchler M, Uhl P, Sauter M, Scherer P, Lan TCT, Zottnick S, Klevenz A, Yang R, Rosl F, Mier W, Riemer AB (2018) Therapeutic vaccination using minimal HPV16 epitopes in a novel MHC-humanized murine HPV tumor model. Oncoimmunology 8:e1524694.

Lambolez F, Arcangeli ML, Joret AM, Pasqualetto V, Cordier C, Di Santo JP, Rocha B, Ezine S (2006) The thymus exports long-lived fully committed T cell precursors that can colonize primary lymphoid organs. Nat Immunol 7:76-82.

Lan P, Tonomura N, Shimizu A, Wang S, Yang YG (2006) Reconstitution of a functional human immune system in immunodeficient mice through combined human fetal thymus/liver and $\mathrm{CD}^{+} 4^{+}$cell transplantation. Blood 108:487-92.

Lanzavecchia A, Sallusto F (2000) Dynamics of T lymphocyte responses: Intermediates, effectors, and memory cells. Science 290:92-97.

Lapidot T, Pflumio F, Doedens M, Murdoch B, Williams DE, Dick JE (1992) Cytokine stimulation of multilineage hematopoiesis from immature human cells engrafted in SCID mice. Science 255:1137-1141.

Lavender KJ, Pang WW, Messer RJ, Duley AK, Race B, Phillips K, Scott D, Peterson KE, Chan CK, Dittmer U, Dudek T, Allen TM, Weissman IL, Hasenkrug KJ (2013) BLT-humanized C57BL/6 Rag2-/-gammac-/CD47-/- mice are resistant to GVHD and develop Band T-cell immunity to HIV infection. Blood 122:40134020 .

Lee JY, Kim DC, Kim HJ (2015) Humanized (SCID) mice as a model to study human leukemia. Biomed Sci Lett 21:51-59.

Lenschow DJ, Walunas TL, Bluestone JA (1996) CD28/B7 system of $\mathrm{T}$ cell costimulation. Annu Rev Immunol $14: 233-258$.

Li W, Kim MG, Gourley TS, McCarthy BP, Sant'Angelo DB, Chang CH (2005) An alternate pathway for CD4 T cell development: Thymocyte-expressed MHC class II selects a distinct $\mathrm{T}$ cell population. Immunity 23:375386.

Li Y, Masse-Ranson G, Garcia Z, Bruel T, Kok A, StrickMarchand H, Jouvion G, Serafini N, Lim AL, Dusseaux M, Hieu T, Bourgade F, Toubert A, Finke D, Schwartz O, Bousso P, Mouquet H, Di Santo JP (2018) A human immune system mouse model with robust lymph node 
development. Nat Methods 15:623-630.

Luce S, Guinoiseau S, Gadault A, Letourneur F, Blondeau B, Nitschke P, Pasmant E, Vidaud M, Lemonnier F, Boitard C (2018) Humanized mouse model to study type 1 diabetes. Diabetes 67:1816-1829.

Manz MG (2007) Human-hemato-lymphoid-system mice: Opportunities and challenges. Immunity 26:537-541.

Masse-Ranson G, Dusseaux M, Fiquet O, Darche S, Boussand M, Li Y, Lopez-Lastra S, Legrand N, Corcuff E, Toubert A, Centlivre M, Bruel T, Spits H, Schwartz O, Levy Y, Strick-Marchand H, Di Santo JP (2019) Accelerated thymopoiesis and improved T-cell responses in HLA-A2/-DR2 transgenic BRGS-based human immune system mice. Eur J Immunol 49:954965.

McCune JM, Namikawa R, Kaneshima H, Shultz LD, Lieberman M, Weissman IL (1988) The SCID-hu mouse: Murine model for the analysis of human hematolymphoid differentiation and function. Science 241:16321639.

McCune JM, Peault B, Streeter PR, Rabin L (1991) Preclinical evaluation of human hematolymphoid function in the SCID-hu mouse. Immunol Rev 124:4562.

Melkus MW, Estes JD, Padgett-Thomas A, Gatlin J, Denton PW, Othieno FA, Wega AK, Haase AT, Garcia JV (2006) Humanized mice mount specific adaptive and innate immune responses to EBV and TSST-1. Nat Med 12:1316-1322.

Morton JJ, Bird G, Refaeli Y, Jimeno A (2016) Humanized mouse xenograft models: Narrowing the tumor-microenvironment gap. Cancer Res 76:6153-6158.

Mosier DE, Gulizia RJ, Baird SM, Wilson DB (1988) Transfer of a functional human immune system to mice with severe combined immunodeficiency. Nature 335:256-259.

Murphy KM, Reiner SL (2002) The lineage decisions of helper T cells. Nat Rev Immunol 2:933-944.
Najima Y, Tomizawa-Murasawa M, Saito Y, Watanabe T, Ono R, Ochi T, Suzuki N, Fujiwara H, Ohara O, Shultz LD, Yasukawa M, Ishikawa F (2016) Induction of WT1-specific human $\mathrm{CD}^{+} \mathrm{T}$ cells from human HSCs in HLA class I Tg NOD/SCID/IL2rgKO mice. Blood 127:722-734.

Niens M, Grier AE, Marron M, Kay TW, Greiner DL, Serreze DV (2011) Prevention of "Humanized" diabetogenic CD8 T-cell responses in HLA-transgenic NOD mice by a multipeptide coupled-cell approach. Diabetes 60:1229-1236.

Obenaus M, Leitao C, Leisegang M, Chen X, Gavvovidis I, van der Bruggen P, Uckert W, Schendel DJ, Blankenstein $\mathrm{T}$ (2015) Identification of human $\mathrm{T}$-cell receptors with optimal affinity to cancer antigens using antigen-negative humanized mice. Nat Biotechnol 33: 402-407.

Peault B, Weissman IL, Baum C, McCune JM, Tsukamoto A (1991) Lymphoid reconstitution of the human fetal thymus in SCID mice with $\mathrm{CD} 34^{+}$precursor cells. J Exp Med 174:1283-1286.

Prinz I, Sansoni A, Kissenpfennig A, Ardouin L, Malissen M, Malissen B (2006) Visualization of the earliest steps of gammadelta $\mathrm{T}$ cell development in the adult thymus. Nat Immunol 7:995-1003.

Punt JA, Suzuki H, Granger LG, Sharrow SO, Singer A (1996) Lineage commitment in the thymus: Only the most differentiated (TCRhibcl-2hi) subset of $\mathrm{CD}^{+} \mathrm{CD}^{+}$ thymocytes has selectively terminated CD4 or CD8 synthesis. J Exp Med 184:2091-2099.

Ridge JP, Di Rosa F, Matzinger P (1998) A conditioned dendritic cell can be a temporal bridge between a CD4+ T-helper and a T-killer cell. Nature 393:474478 .

Romero P, Zippelius A, Kurth I, Pittet MJ, Touvrey C, Iancu EM, Corthesy P, Devevre E, Speiser DE, Rufer N (2007) Four functionally distinct populations of human effector-memory $\mathrm{CD}^{+} \mathrm{T}$ lymphocytes. J Immunol 
178:4112-4119.

Schoenberger SP, Toes RE, van der Voort EI, Offringa R, Melief CJ (1998) T-cell help for cytotoxic T lymphocytes is mediated by CD40-CD40L interactions. Nature 393:480-483.

Serr I, Furst RW, Achenbach P, Scherm MG, Gokmen F, Haupt F, Sedlmeier EM, Knopff A, Shultz L, Willis RA, Ziegler AG, Daniel C (2016) Type 1 diabetes vaccine candidates promote human Foxp $3\left(^{+}\right)$Treg induction in humanized mice. Nat Commun 7:10991.

Shultz LD, Brehm MA, Garcia-Martinez JV, Greiner DL (2012) Humanized mice for immune system investigation: Progress, promise and challenges. Nat Rev Immunol 12:786-798.

Shultz LD, Lyons BL, Burzenski LM, Gott B, Chen X, Chaleff S, Kotb M, Gillies SD, King M, Mangada J, Greiner DL, Handgretinger R (2005) Human lymphoid and myeloid cell development in NOD/LtSz-scid IL2R gamma ${ }^{\text {null }}$ mice engrafted with mobilized human hemopoietic stem cells. J Immunol 174:6477-6489.

Shultz LD, Saito Y, Najima Y, Tanaka S, Ochi T, Tomizawa M, Doi T, Sone A, Suzuki N, Fujiwara H, Yasukawa M, Ishikawa F (2010) Generation of functional human T-cell subsets with HLA-restricted immune responses in HLA class I expressing NOD/SCID/ IL2r gamma ${ }^{\text {null }}$ humanized mice. Proc Natl Acad Sci USA 107:13022-13027.

Shultz LD, Schweitzer PA, Christianson SW, Gott B, Schweitzer IB, Tennent B, McKenne S, Mobraaren L, Rajan TV, Greiner DL (1995) Multiple defects in innate and adaptive immunologic function in NOD/LtSz-scid mice. J Immunol 154:180-191.

Smith DJ, Lin LJ, Moon H, Pham AT, Wang X, Liu S, Ji S, Rezek V, Shimizu S, Ruiz M, Lam J, Janzen DM, Memarzadeh S, Kohn DB, Zack JA, Kitchen SG, An DS, Yang L (2016) Propagating humanized blt mice for the study of human immunology and immunotherapy. Stem Cells Dev 25:1863-1873.
Song J, Willinger T, Rongvaux A, Eynon EE, Stevens S, Manz MG, Flavell RA, Galan JE (2010) A mouse model for the human pathogen Salmonella typhi. Cell Host Microbe 8:369-376.

Steinman RM (1991) The dendritic cell system and its role in immunogenicity. Annu Rev Immunol 9:271-296.

Strowig T, Gurer C, Ploss A, Liu YF, Arrey F, Sashihara J, Koo G, Rice CM, Young JW, Chadburn A, Cohen JI, Munz C (2009) Priming of protective T cell responses against virus-induced tumors in mice with human immune system components. J Exp Med 206:1423-1434.

Suzuki M, Takahashi T, Katano I, Ito R, Ito M, Harigae H, Ishii N, Sugamura K (2012) Induction of human humoral immune responses in a novel HLA-DRexpressing transgenic NOD/Shi-scid $/ \gamma c^{\text {null }}$ mouse. Int Immunol 24:243-252.

Takahama Y (2006) Journey through the thymus: Stromal guides for T-cell development and selection. Nat Rev Immunol 6:127-135.

Takaki T, Marron MP, Mathews CE, Guttmann ST, Bottino R, Trucco M, DiLorenzo TP, Serreze DV (2006) HLA$A^{*} 0201$-restricted $\mathrm{T}$ cells from humanized NOD mice recognize autoantigens of potential clinical relevance to type 1 diabetes. J Immunol 176:3257-3265.

Tary-Lehmann M, Saxon A (1992) Human mature T cells that are anergic in vivo prevail in SCID mice reconstituted with human peripheral blood. J Exp Med 175:503516.

Tary-Lehmann M, Saxon A, Lehmann PV (1995) The human immune system in hu-PBL-SCID mice. Immunol Today 16:529-533.

Thomas S, Klobuch S, Sommer M, van Ewijk R, Theobald M, Meyer RG, Herr W (2014) Human CD8 ${ }^{+}$memory and $\mathrm{EBV}$-specific $\mathrm{T}$ cells show low alloreactivity in vitro and in $\mathrm{CD} 34^{+}$stem cell-engrafted NOD/SCID/IL2R $\gamma \mathrm{c}^{\text {null }}$ mice. Exp Hematol 42:28-38.

Traggiai E, Chicha L, Mazzucchelli L, Bronz L, Piffaretti JC, Lanzavecchia A, Manz MG (2004) Development of 
a human adaptive immune system in cord blood celltransplanted mice. Science 304:104-107.

Tsuchida M, Brown SA, Tutt LM, Tan J, Seehafer DL, Harris JP, Xun CQ, Thompson JS (1997) A model of human anti-T-cell monoclonal antibody therapy in SCID mice engrafted with human peripheral blood lymphocytes. Clin Transplant 11:522-528.

Tuckett AZ, Thornton RH, O'Reilly RJ, van den Brink MRM, Zakrzewski JL (2017) Intrathymic injection of hematopoietic progenitor cells establishes functional $\mathrm{T}$ cell development in a mouse model of severe combined immunodeficiency. J Hematol Oncol 10:109.

Velardi E, Tsai JJ, Holland AM, Wertheimer T, Yu VW, Zakrzewski JL, Tuckett AZ, Singer NV, West ML, Smith OM, Young LF, Kreines FM, Levy ER, Boyd RL, Scadden DT, Dudakov JA, van den Brink MR (2014) Sex steroid blockade enhances thymopoiesis by modulating Notch signaling. J Exp Med 211:23412349.

Walsh NC, Kenney LL, Jangalwe S, Aryee KE, Greiner DL, Brehm MA, Shultz LD (2017) Humanized Mouse Models of Clinical Disease. Annu Rev Pathol 12:187215.

Watanabe Y, Takahashi T, Okajima A, Shiokawa M, Ishii
N, Katano I, Ito R, Ito M, Minegishi M, Minegishi N, Tsuchiya S, Sugamura K (2009) The analysis of the functions of human B and T cells in humanized NOD/ shi-scid/gammac null (NOG) mice (hu-HSC NOG mice). Int Immunol 21:843-858.

Wege AK, Melkus MW, Denton PW, Estes JD, Garcia JV (2008) Functional and phenotypic characterization of the humanized BLT mouse model. Curr Top Microbiol Immunol 324:149-65.

Williams SS, Umemoto T, Kida H, Repasky EA, Bankert RB (1992) Engraftment of human peripheral blood leukocytes into severe combined immunodeficient mice results in the long term and dynamic production of human xenoreactive antibodies. J Immunol 149:28302836.

Zakrzewski JL, Kochman AA, Lu SX, Terwey TH, Kim TD, Hubbard VM, Muriglan SJ, Suh D, Smith OM, Grubin J, Patel N, Chow A, Cabrera-Perez, Radhakrishnan R, Diab A, Perales MA, Rizzuto G, Menet E, Pamer EG, Heller G, Zuniga-Pflucker JC, Alpdogan O, van den Brink MR (2006) Adoptive transfer of T-cell precursors enhances $\mathrm{T}$-cell reconstitution after allogeneic hematopoietic stem cell transplantation. Nat Med 12:1039-1047. 